\title{
The Priority Importance of Economic Motivation Factors Against Risks for Green Building Development in Malaysia
}

\author{
Farid Ezanee Mohamed Ghazali ${ }^{1}$, Rozana Zakaria ${ }^{2 *}$,Eeydzah Aminudin ${ }^{3}$, Lee Yong Siang ${ }^{4}$, \\ Gamal Alqaifi ${ }^{5}$, Darul Nafis Abas ${ }^{6}$, Nur IzieAdiana Abidin ${ }^{7}$, Siti Mazzuana Shamsuddin ${ }^{8}$ \\ ${ }^{1,4}$ School of Civil Engineering, Engineering Campus, Universiti Sains Malaysia, 14300 Nibong Tebal, \\ Penang, Malaysia \\ 2,3,5,6,7 Department of Structures and Materials, Faculty of Civil Engineering, Universiti Teknologi \\ Malaysia, Johor, Malaysia \\ ${ }^{8}$ Faculty of Achitecture, Planning and Surveying, Universiti Teknologi Mara, Shah Alam, Selangor, \\ Malaysia
}

\begin{abstract}
Green building development is an emerging paradigm for the construction industry practice all around the world. The establishement of Green Building rating tool helps to assess the whole life cycle process in planning to operation in a building. The Malaysian construction industry recognizes buildings that have been assessed using established green building tool such Green Building Index, Green RE or My CREST. Eventhough these rating tools provide motivation factors in its criteria and sub-criteria to promote sustainability in Malaysia buildings, there is still a major doubt to developers in terms of risks that may hinder their investments in green buildings. This paper highlights the priority importance of economic motivation factors against risks in the green building development in Malaysia. The data presented in this paper have been mainly derived from responses received through questionnaires completed by building stakeholders involved in green building developments. In order to determine the priority importance of economic motivation factors and risks identified for green building development, the questionnaire outcomes have been thoroughly assessed using the Analytical Hierarchy Process (AHP) method. As a result, lack of government incentive and high capital cost, which classified under green building risks, are the two key factors with highest priority importance that influenced most of the decision making for green building development in Malaysia. The results show green buildings have proliferated as governmental support and incentives with more exampler of higher profit return of investment in enhancing developers preference for green building development.
\end{abstract}

* Corresponding author: rozana@utm.my 


\section{Introduction}

The green building movement has revolutionized the way the architectural industry envisions and designs buildings for promotion of environmental sustainability, the establishment of green building certification systems globally is one of the most prominent [1]. However, green building faces various types of risks that hinder the penetration of this investment into the industry of sustainable construction. Many studies have highlighted the risks and challenges that face the investment of green buildings in various types of industries $[2,3,4,5,6,7,8]$ Poor management of risk in construction projects may result in the failure to comply with the delivery date and approved budgets, which take place due to lack of appropriate procurement strategy, act of God as well as economy recession on prices of materials. In order to get prepare with the preventive action, contingency sum is needed and it is a provision for every construction project [7]. The identity of each risk also is an important step in risk managing and is by all mean the most difficult especially when it comes to the identification of each source of risk [9]. Thus, the consideration on the influence of each risk factor, will simplify the analysis and management of the risk itself [10]. Among the factors that negatively affect the interest of investors and the public in general regarding the green investment which represent risks factors are a lack of knowledge in sustainable green design and construction in learning institutions, a lack of experience related to the construction of green building in the realms of architecture and designing, the high cost when constructing buildings with green features [11]. The great heterogeneity for developers is the capital cost that contributes in green building development. This has made it challenging to understand the influenced cost implications in improving the performance of green building concept for building occupancy building, the selection of building material and green technology.

\section{Risk in Green Building Development}

In risk point of view, future cost and availability of green building materials can represent a risk factor to the investment of green building. The cost of green building construction can be increased by the time factor effects due to the unfamiliarity of green investment by the contractors and subcontractors [12]. Negative perception of green building investment in general summarize a cost risk factor of the investment [13]. While technical difficulties represent an internal risk factor in terms of the right way of green building construction due to different environment of practice [14]. Some of the previous research studies clarified that green building cost is higher in terms of material cost, build and maintenance $[13,15,16]$. [17] identified that some design codes of building do not allow the implementation of green features because the codes are for conventional buildings. In other words, the conventional codes may restrict limited options to the developers such as the choice of design, construction system and new green technology and materials that shall be applied into almost all green building development. According to [11], the difficulty of sourcing for building materials required by developers, the regulatory procedures that inhibit green material production and the fact that there are limited green building examples to emulate The findings clarified that the time frame of the green project can be lengthened due to the lack of expertise and green resources in some communities [18] determined that sustainability measures are not considered by stakeholders and sometimes not even requested by clients while some green features were cancelled in order to achieve others. This statement shows that unreliable sustainable measures with the lack of perception and awareness can be risk factors to the investment of green building. Sustainable measures faces lots of challenges such as cost factors whereby investors may not fund the green project due to the sustainable measures requirements. 
Majority of the green building experts believes that the governments can effectively play a major role in promoting sustainable development such as green buildings [19]. At the same time, Governments can enforce the rules and regulations to support green building development. However, government policies and technical standards shall be adopted to satisfy the sustainable measures in order to avoid any issues that may result due to the conflict of conditions of the construction site [18]. [20] highlighted a fact that market-based incentives are one of the most effective and efficient tools to address market failure together with non-market problems to improve the situation for green buildings development. On the other hand, it has been identified that several risks and challenges may hinder the development of green buildings in Asia including Malaysia such as: lack of awareness, Lack of knowledge and training programs on sustainable design, higher cost, special materials, rules and regulation, lack of demonstration, lack of technology and lack of demand [21]. Another study has shown that wrong perception of transition and the expected return on investment represents the highest degree of constraints that may obstruct the development of green buildings [6] including lack of information and the lack of effective management of financial resources [13]. In the same context, lack of financial support, professional experts and implementing of green technologies are considered to be among the key challenges in both public and private sector [22]. Table 1 indicates a summarised ten significant risks that are associated to green building development in Malaysia.

Table 1. Risk Factor in Green Building Development

\begin{tabular}{|c|l|}
\hline Item & \multicolumn{1}{|c|}{ Risk Factor of Green Building Development } \\
\hline 1 & High Capital Cost \\
\hline 2 & Availability of Experts \\
\hline 3 & Lack of Awareness \\
\hline 4 & Lack of Enforcement from Government \\
\hline 5 & Availability of Green Materials \\
\hline 6 & Uncertainty of Future Material Cost \\
\hline 7 & Technical Difficulty During Construction \\
\hline 8 & Limited Availability of Green Suppliers \\
\hline 9 & Lack of quantitative evaluation tools for green performance \\
\hline 10 & High Capital Cost \\
\hline
\end{tabular}

\section{Economic Motivation in Green Building Development}

Numerous study show that green buildings does performed as more efficient and more sustainable during operations (energy efficiency and water efficiency) as this improvement enhance as its benefits the owner to derive economic value through green marketing. Still, limited rigorous empirical evidence regarding the economics, especially in costeffectiveness of investments to achieve green building development is being claimed by developer.

Economic motivation factors such organizational, social, environmental and economic are among the key inspiration for the developers to drive forward green building development not only in Malaysia but also other countries around the world. Through identification of economic motivation factors, developer should gain the benefits not only for them but also to the human being and environment.

[23] had simplified ten economic motivation factors for green building development in Malaysia as shown in Table 2. 
Table 2. Economic Motivation Factor in Green Building Development [23]

\begin{tabular}{|c|l|}
\hline Item & \multicolumn{1}{|c|}{ Risk Factor of Green Building Development } \\
\hline 1 & Long Term Value for Money Offset Cost \\
\hline 2 & High Market Demand \\
\hline 3 & Energy Efficiency Cost Savings \\
\hline 4 & Financial Incentive \& Tax Exemption \\
\hline 5 & Whole Life Cycle Design implies economic benefits \\
\hline 6 & Reduce Water Consumption Cost \\
\hline 7 & Minimal Fuel/Transportation Cost \\
\hline 8 & Low Waste Disposal Cost \\
\hline 9 & Higher Return of Investment \\
\hline 10 & Minimum Maintenance \& Repair Costs \\
\hline
\end{tabular}

Based on the ambiguity on green building and question above, there is always a question to developer whether to embark and invest on green building development i.e. whether risks associated to green building development always being influenced or emerged as a result of higher initial cost. Therefore, this paper embarked with the analysis to determine the priority importance of economic motivation factors against risks for green building development in Malaysia.

\section{Methodology}

The quantitative approach is being applied in this study in order to analyze the understanding of practitioners in Malaysia on green building besides determining the influencing factors, which could have a significant impact towards decisions related to green building development. A set of questionnaires had been distributed to various respondents involved in construction and development projects both in Johor Bahru and Kuala Lumpur mainly to the construction practitioners such as contractor, consultant, developer and government servant.

However, the distribution method was not designed to achieve a random or representative sample, and the data were not meant to be subjected to tests of statistical significance. 69 questionnaire survey had been received in return from the involved respondents. The demographic information of the respondents is as follows; $13 \%$ (9) of respondents had more than 21 years of working experience, $11.6 \%$ (8) have between 16-20 years of working experience, While another 23.2\% (16) have between 11-15 years of working experience and another $15.9 \%$ (11) have between 6-10 years of working experience. In majority $36.2 \%(25)$ had 1-5 years of working experience. For respondent working sector $21.75(15)$ are from consultants, $24.6 \%$ (17) are from contractor, $40.6 \%$ (28) are from developers and $13 \%(9)$ are from government related construction working sector.

Once the criticality and importance of both key success elements and critical success factors have been determined, the Analytical Hierarchy Process (AHP) approach, which supports any multi-criteria decision-making situations by breaking down problems into relevant hierarchical levels, has been used in the data analysis. [24] regarded the AHP pairwise comparison matrix as a method that provides more valid results than the Likert-based survey. [25] have generalized the fact that AHP approach allows decision makers to structure complex problems in the form of a hierarchy such as the goal, criteria and alternative compared to other decision-making approaches. Table 3 portrays the fundamental intensity scales developed by [26] (in [27]) for AHP decision-making models. The fundamental concept of pairwise comparison in the AHP is to assess the priority importance of a criterion over another that leads to achieving a hierarchy objective. For example, if the criticality and priority importance of criterion " $\mathrm{A}$ " is found to be essential or 
strong over "B" in pairwise comparison, then an intensity scale of 5 should be awarded to the former. The intensity scale "1" usually represents two activities that have an equal priority importance to the objective when they are being evaluated in the pairwise comparison.

Table 3. Intensity Scale for AHP Pairwise Comparison (Source: [26] (in [27])

\begin{tabular}{|c|c|c|}
\hline $\begin{array}{l}\text { Intensity of } \\
\text { Importance }\end{array}$ & Definition & Explanation \\
\hline 1 & Equal Importance & Two activities contribute equally to the objective \\
\hline 3 & $\begin{array}{l}\text { Weak Importance of } \\
\text { one over another }\end{array}$ & $\begin{array}{l}\text { Experience and judgement strongly favour one activity } \\
\text { over another }\end{array}$ \\
\hline 5 & $\begin{array}{l}\text { Essential or strong } \\
\text { importance }\end{array}$ & $\begin{array}{l}\text { Experience and judgement strongly favour one activity } \\
\text { over another }\end{array}$ \\
\hline 7 & $\begin{array}{l}\text { Very strong } \\
\text { importance }\end{array}$ & $\begin{array}{l}\text { An activity is strongly favoured and its dominance } \\
\text { demonstrated in practice }\end{array}$ \\
\hline 9 & $\begin{array}{l}\text { Absolute } \\
\text { importance }\end{array}$ & $\begin{array}{l}\text { The evidence favouring one activity over another is of the } \\
\text { highest possible order or affirmation }\end{array}$ \\
\hline $2,4,6,8$ & $\begin{array}{l}\text { Intermediate values } \\
\text { between the two } \\
\text { adjacent judgements }\end{array}$ & When compromise is needed \\
\hline
\end{tabular}

\section{Results and Findings}

Figure 1 indicates the decision-making hierarchy for factor affecting most to the decision making of Green Building Development which composed of three (3) levels; Goal, Factor and Sub-Factor as a result of cumulative questionnaire-based outcomes generated from a series of interviews carried out with 69 respondents.
L1: Goal
Green Building Risks
- Lack of Government Incentive
- High Capital Cost
Factors
- Availability of Experts
affecting
Green
Building
Development
in Malaysia
- Lack of Awareness
- Lack of Enforcement from Government
- Availability of Green Materials
- Uncertainty of Future Material Cost
- Technical Difficulty During Construction
- Limited Availability of Green Suppliers
- Lack of quantitative evaluation tools for green performance
Green Building Economic Motivation Factors
- Long Term Value for Money Offset Cost
- High Market Demand
- Energy Efficiency Cost Savings
- Financial Incentive \& Tax Exemption
- Whole Life Cycle Design implies economic benefits
- Reduce Water Consumption Cost
- Minimal Fuel/Transportation Cost
- Low Waste Disposal Cost
- Higher Return of Investment
- Minimum Maintenance \& Repair Costs

Figure 1. The Hierarchy of Decision Making Factors for Green Building Development

In pairwise comparisons, each of the identified factor and sub-factor are assessed against the hierarchy goal, which revolves around the factor affecting most to the decision making of Green Building Development via the Expert Choice software. The relative importance of each factor and sub-factor is compared with other factor and sub-factor identified within the 
same decision level with respect to the hierarchy goal, whichever is higher than the assessed factor.

Figure 2 shows pairwise comparisons of factor identified for level 2 in respect to the hierarchy goal. As a result, the Green Building Risks has greater impact compared to Green Building Economic Motivation Factors for the factor affecting most to the decision making of Green Building Development as the scoring 3 leans towards to Green Building Risks. The score 3 given to the Green Building Risks indicates its priority intensity that gives weak importance against Green Building Economic Motivation Factors. Figure 3 shows the overall priority ranking of factor affecting most to the decision making of Green Building Development which the result is composed of all levels in decision-making hierarchy as shown in Figure 1. It is apparent from the research findings that lack of government incentive, followed by high capital cost are two major factors affecting most to the decision making of green building development in Malaysia which fall under green building risk.

Most of the respondents agreed that lack of government incentives to the decision making for green building development. This result can be jusitifed through findings by [28] that supported the contention and consistent of [29] who asserts that the construction industry seems to be lagging in terms of the provision of incentives to developers who meet green ratings, and consultant team members who engage in green design practices on their projects and the lack of incentives for demonstrating best green practice. The provision of incentives will undoubtedly reduce the high up front cost for green projects. [30] support this notion by asserting that incentive provisions are used in construction contracts to reduce contract costs, to minimize contract duration and to maintain acceptable levels in health and safety, productivity, technological progress, innovation, management efficiency, and quality of construction. On the other side, five states in U.S offer limited grants, such as in Kentucky, it's offer the symbolic gestures promoting certification. Besides that, they also offers variety of innovative policy designs and incentives, including property tax reassessment moratoriums, green funds, parking incentives, electric bill discounts and green roof mandates.

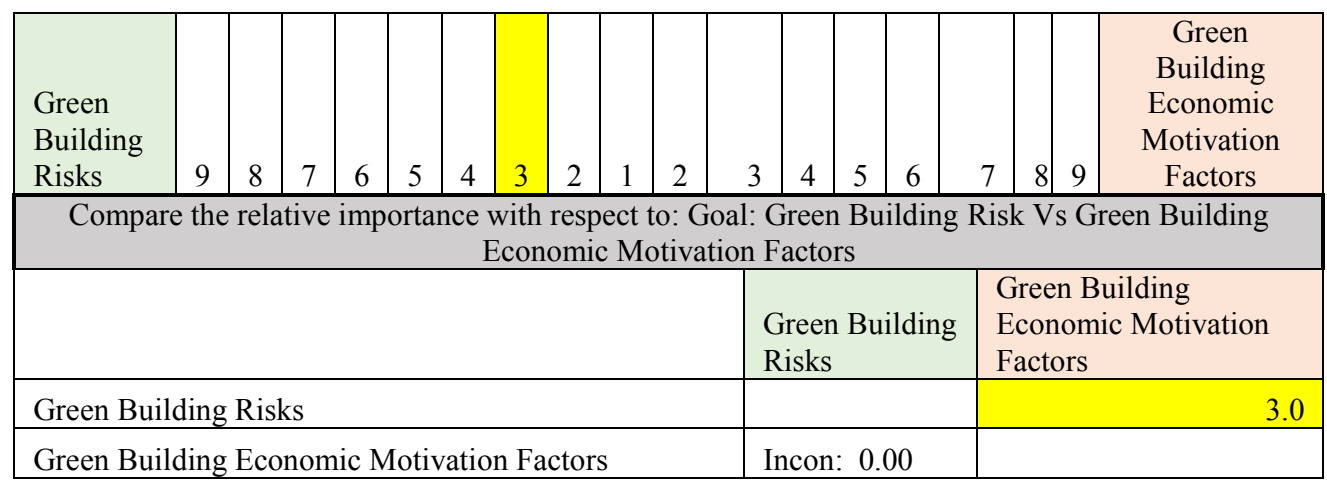

Figure 2. Pairwise Comparison on Factor affecting most to the decision making of Green Building Development in Level 2

Besides that, many respondents also concerned that adopting green features into their buildings will involve high capital cost. Compared to conventional buildings, green building projects are often perceived as having higher initial design and constructions costs. The lack of attention to the costs associated with green construction seems to be a global phenomenon. [17] states that one of the major barriers is the need for reliable cost information for green features, without this information, it is difficult for the market to justify the occasionally higher up-front costs for a green development project. 


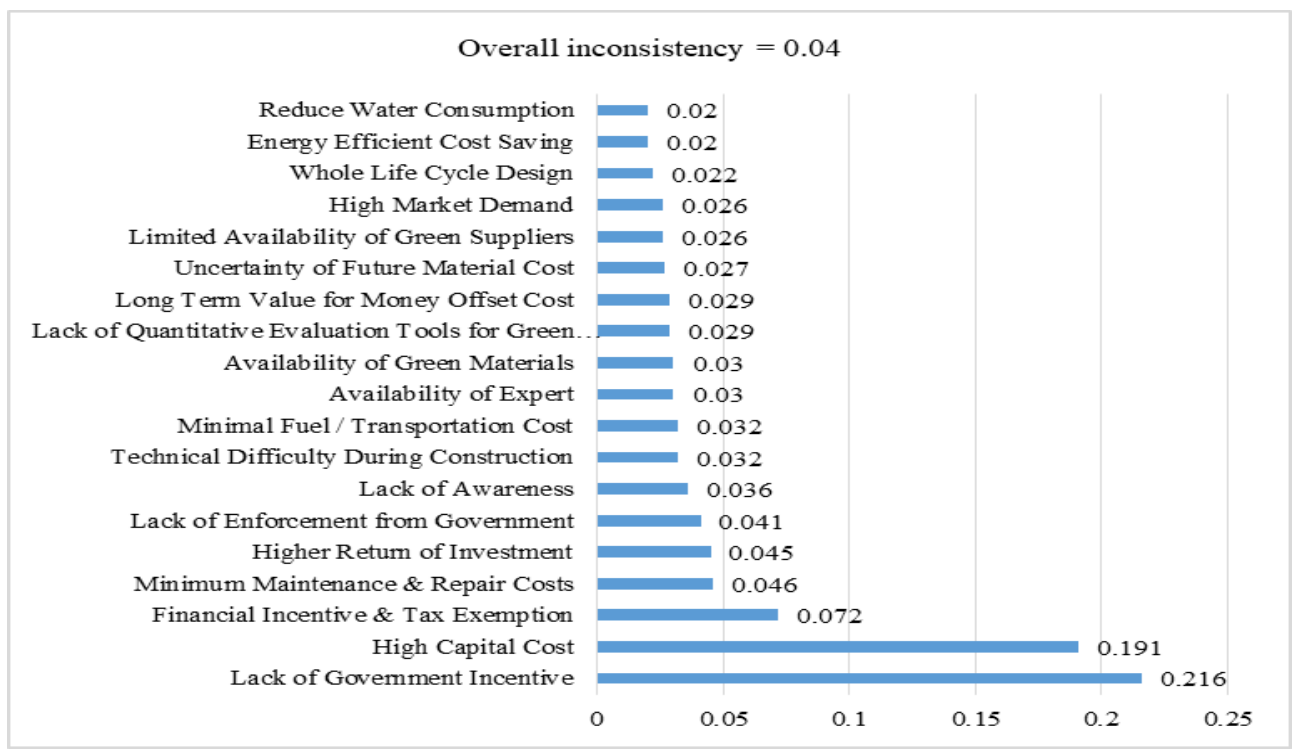

Figure 3. The Overall Priority Ranking of Factor affecting most to the decision making of Green Building Development

[31] reveal that there is still little published data about actual cost premiums for green buildings. For instance, in the United States this information gap is exacerbated by the fact that the USGBC does not require that cost information be included with submissions for LEED certification. Many developers keep cost information proprietary. Accordingly, [32] acknowledges that there are more ways to expand the four pillars of sustainability and one of the ways is to expand Full-Cost Pricing to True-Cost Pricing. Debatably, the True-Cost Pricing goes beyond covering the costs of the infrastructure and includes long-term environmental and community externalities, such as for example, energy savings, green space, and green job creation. While there has been a plethora of research seeking to determine the direct or tangible costs of green building, the indirect or intangible costs remain unexplored in construction. [33] argues that this is because it is difficult, if not impossible to quantify such costs in purely monetary terms. The opinion embedded with [17] emphasizes on the need to look at the indirect costs as well when determining the total upfront or capital costs of green construction.

\section{Conclusion}

Despite the spur of growth in green buildings across Asia, the shift towards more sustainable goals still lags in Malaysia due to several key challenges. The study of green buildings is further hampered by financial incentives such as lower local government taxes would encourage green building adoption in market. Through financial premiums associated with desired building improvements helps align with costs which green building projects are often perceived as higher capital cost compared to conventional buildings. Capital costs for green building development are often a primary barrier to realizing high performance buildings that can save energy. There is clearly a need to create a coordinated knowledge hub to document and provide the existing and emerging information for green building development especially on the barriers of implementation of government incentive and having high capital cost in this green industry. Understanding the origins and green 
building risk basically related to green building economic motivation factors which requires an approach of green building practices adopted, and the overall (including uncertified) penetration of green building practices in the built environment.

\section{References}

1. Liang, H.-H., Chen, C.-P., Hwang, R.-L., Shih, W.-M., Lo, S.-C., \& Liao, H.-Y. Satisfaction Of Occupants Toward Indoor Environment Quality of Certified Green Office Buildings in Taiwan. Building And Environment, 72, 232-242. (2014).

2. Al Zubaidi, H., \& Al Otaibi, S. An Empirical Approach for Identifying Critical TimeOvrerun Risk Factors in Kuwait's Construction Projects. Journal of Economic and Administrative Sciences, 24(2), 35-53. (2008).

3. Hoffman, A. J., \& Henn, R. Overcoming the Social and Psychological Barriers to Green Building. Organization \& Environment, 21(4), 390-419. (2008).

4. Kasai, N., \& Jabbour, C. J. C. Barriers to Green Buildings at two Brazilian Engineering Schools. International Journal of Sustainable Built Environment, 3(1), 87-95. (2014).

5. Koh, S., Saad, S., Ahmed, A., Kayis, B., \& Amornsawadwatana, S. A Review of Techniques for Risk Management in Projects. Benchmarking: An International Journal, 14(1), 22-36. (2007).

6. Marker, A. W., Mason, S. G., \& Morrow, P. Change Factors Influencing The Diffusion and Adoption of Green Building Practices. Performance Improvement Quarterly. 26(4), 524. (2014).

7. Mills, A. A Systematic Approach to Risk Management for Construction. Structural survey. 19(5), 245-252. (2001).

8. Yang, R. J., \& Zou, P. X. Stakeholder-Associated Risks and Their Interactions in Complex Green Building Projects: A Social Network Model. Building and Environment, 73, 208-222. (2014).

9. Tchankova, L. Risk Identification-Basic Stage in Risk Management.Environmental Management and Health, 13(3), 290-297. (2002).

10. Bajaj, D., Oluwoye, J., \& Lenard, D. An Analysis Of Contractors' Approaches to Risk Identification in New South Wales, Australia. Construction Management \& Economics.

15(4), 363-369. (1997).

11. Shafii, F., \& Othman, M. Z. Greening Engineering Education for Sustainable

Development. The Conference On Sustainable Building South-East Asia. Johor (Malaysia). 416-421. (2007).

12. Griffin, C., Knowles, C., Theodropoulos, C., \& Allen, J. Barriers To The Implementation Of Sustainable Structural Materials In Green Buildings. Paper Presented At The Structures \& Architecture: ICSA 2010-1st International Conference on Structures \& Architecture, July 21-23 July, 2010 in Guimaraes, Portugal. (2010).

13. Richardson, G. R., \& Lynes, J. K. Institutional Motivations and Barriers to the Construction of Green Buildings on Campus: A Case Study Of The University Of Waterloo, Ontario. International Journal of Sustainability in Higher Education, 8(3), 339354. (2007).

14. Zhang, X., Platten, A., \& Shen, L. Green Property Development Practice in China: Costs And Barriers. Building and Environment. 46(11), 2153-2160. (2011).

15. Lam, P. T., Chan, E. H., Poon, C., Chau, C., \& Chun, K. Factors Affecting the Implementation of Green Specifications in Construction. Journal of Environmental Management, 91(3), 654-661 (2010).

16. Shi, Q., Zuo, J., Huang, R., Huang, J., \& Pullen, S. Identifying The Critical Factors For Green Construction-An Empirical Study In China. Habitat International, 40, 1-8 (2013).

17. Choi, C. Removing Market Barriers to Green Development: Principles and Action Projects to Promote Widespread Adoption of Green Development Practices. Journal of 
Sustainable Real Estate, 1(1), 107-138 (2009).

18. Williams, K., \& Dair, C. What is Stopping Sustainable Building in England? Barriers Experienced by Stakeholders in Delivering Sustainable Developments. Sustainable Development-Bradford, 15(3), 135 (2007).

19. Samari, M., Godrati, N., Esmaeilifar,R., Olfat, P., Mohd Shafie, M.W. "The Investigation of the Barriers in Developing Green Building in Malaysia", Modern Applied Science, 7, 2. (2013).

20. Keiner, M. The future of sustainability: Springer. (2006).

21. Shafii, F., Ali, Z. A., and Othman, M. Z. Achieving Sustainable Construction in The Developing Countries Of Southeast Asia. Paper Presented at the Proceedings Of The 6th Asia-Pacific Structural Engineering and Construction Conference (APSEC 2006), Kuala Lumpur, Malaysia, 5-6 (2006).

22. Xiaolu, Z. Investigation of Factors Restraining the Implementation of Green in Mainland China, Organisation, Technology \& Management in Construction. 6(3) (2014). 23. Darul Nafis Abas. The Motivation Factors in the Provision Of Green Building Criteria in Green Building Development. Thesis Universiti Teknologi Malaysia (2016).

24. Fong, P.S.K. and Choi, S.K.Y. Final Contractor Selection Using The Analytical Hierarchy Process., Construction Management and Economics, vol. 18, pp. 547-557. (2000).

25. Acharya, N.K, Young D.L, and Jung, K.K . Critical Construction Conflicting Factors Identification Using Analytical Hierarchy Process. KSCE Journal of Civil Engineering, vol. 10 (3), pp. 165-174 (2006).

26. Saaty, T.L. How To Make A Decision: The Analytic Hierarchy Process, European Journal Of Operational Research, Volume 48, Issue 1, pp. 9-26 (1990).

27. Mahdi, I.M. and Alreshaid, K. Decision Support System for Selecting The Proper Delivery Method Using Analytical Hierarchy Process (AHP), International Journal of Project Management, Volume 25,pp. 564-572 (2005).

28. Ndihokubwayo, R., Crafford, G.J. \& Buys, F.. Consultant Team Members'

Performance Evaluation Against Incentives Towards The Achievement Of Green Building Principles. Proceedings of 6th Annual SACQSP Research Conference on "Green Vision 20/20”, Cape Town, South Africa, 20-21 June 2013 (2013).

29. Milne, N. The Rands and Sense of Green Building: Re-visited. Building the Business Case for Green Commercial buildings in South Africa. Green Building Council, Cape Town, South Africa (2012).

30. Arditi, D. \& Yasamis, F. Incentive / Disincentive Contracts: Perceptions of Owners and Contractors, Journal of Construction Engineering and Management. 124 (5), 361-373 (1998).

31. Kats, G., \& Capital, E. The cost and financial benefits of green buildings: A Report to California's sustainable building task force, developed for the Sustainable Building Task Force, California, USA (2003)

32. Nelson, V.I. Sustainable Infrastructure Management, Coalition for Alternative Wastewater Treatment White Paper (2008)

33. Love, P.E.D. Auditing the Indirect Consequences of Rework In Construction: A Case Based Approach, Managerial Auditing Journal, 17(3), 138-146 (2002). 